\title{
Condições objetivas do trabalho docente na modalidade remota no contexto da COVID-19: uma análise correlacional em instituições públicas e privadas
}

\section{Objective conditions of teaching in remote modes in the context of COVID-19: a correlational analysis in public and private institutions}

Fernanda Landolfi Maia*

Kelen Aparecida da Silva Bernardo**

\begin{abstract}
Resumo: Devido à propagação da pandemia da COVID-19, o trabalho remoto tornou-se a principal medida de segurança para a continuidade das atividades laborais. Diversas categorias profissionais, de diferentes setores, foram atingidas e neste artigo dá-se destaque ao trabalho docente. A suspensão das aulas presenciais levou docentes de todos os níveis de ensino, das esferas pública e privada, a exercerem suas atividades na modalidade de Ensino Remoto Emergencial (ERE). A partir de metodologia qualitativa e quantitativa, o presente artigo tem como objetivo tecer uma análise correlacional das condições de trabalho remoto - no contexto da pandemia - dos docentes vinculados ao setor público e privado, nos mais diversos níveis de ensino (fundamental, médio, superior). A partir do banco de dados da pesquisa "Trabalho remoto/home office no contexto da pandemia COVID-19", com filtro para o setor educacional, foi possível identificar, entre os achados do levantamento, que o trabalho remoto em instituições públicas e privadas,
\end{abstract}

\footnotetext{
* Doutora em Sociologia pela UFPR. Mestre em Educação pela PUC/PR. Graduada em Ciências Sociais pela UFPR e Secretariado Executivo pela Faculdade Internacional de Curitiba. Docente do Setor de Educação Profissional e Tecnológica e do Programa de Mestrado Profissional em Sociologia da Universidade Federal do Paraná. Membro do Grupo de Estudos e Pesquisa Trabalho e Sociedade (GETS/UFPR). Pesquisadora da Rede de Estudos e Monitoramento Interdisciplinar da Reforma Trabalhista (REMIR). E-mail: fernanda.landolfi@gmail.com.

** Doutora em Sociologia pela Universidade Federal do Paraná. Mestre em Ciências Sociais Aplicadas e Graduada em Serviço Social pela UEPG. Docente temporária do Departamento de Serviço Social da UEPG. Membro do Grupo de Estudos e Pesquisa Trabalho e Sociedade (GETS/UFPR). Pesquisadora da Rede de Estudos e Monitoramento Interdisciplinar da Reforma Trabalhista (REMIR). E-mail: kelenbernardo18@gmail.com.
}

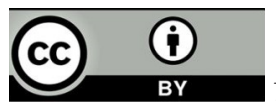


assume especificidades distintas, como critérios para metas mais presentes no setor privado. No entanto, questões como intensificação do trabalho e a dinâmica de fragilização do ofício da categoria docente são similares em ambos os setores.

Palavras-chave: Trabalho remoto. Condições do trabalho docente. Intensificação. Isolamento social.

\begin{abstract}
Due to the spread of the COVID-19 pandemic, remote work has become the main safety measure for the continuity of work activities. Several professional categories from different sectors were reached and in this article the teaching work is emphasized. The suspension of classroom classes led teachers from all levels of education, from the public and private spheres, to carry out their activities in the form of Emergency Remote Teaching (ERE). Based on a qualitative and quantitative methodology, this article aims to weave a correlational analysis of remote working conditions - in the context of the pandemic - of teachers linked to the public and private sectors. From the database of the educational sector of the research "Remote work/home office in the context of the COVID-19 pandemic", it was possible to identify that remote work in public and private institutions takes on different specificities as, for example, criteria for goals more common in the private sector private. However, issues such as work intensification and the weakening dynamics of the teaching profession are similar in both sectors.
\end{abstract}

Keywords: Remote work. Conditions of teaching work. Intensification. Social isolation.

\title{
Introdução
}

O contexto da Pandemia da Covid-19 desencadeou, em 2020, um cenário de mobilização global objetivando a contenção da disseminação do vírus. Entre as recomendações da Organização Mundial da Saúde (OMS), o isolamento social tornou-se a principal ação, afetando todos os setores da sociedade. No campo educacional, as atividades presenciais foram suspensas, sendo transferidas para o ambiente digital, de forma urgente e provisória, implicando em mudanças, adaptações e novos aprendizados, tanto dos docentes como dos discentes. No presente estudo, damos relevância às condições de trabalho dos docentes na modalidade remota. Essa pesquisa tem como objetivo tecer uma análise correlacional entre as condições e relações de trabalho dos docentes na modalidade remota, vinculados ao setor público e privado no contexto da pandemia.

Segundo documento da Organização Internacional do Trabalho a "COVID- 19 e o setor da educação" (OIT, 2020), as aulas foram interrompidas, em março de 2020, para cerca de 1,58 milhões de estudantes em escala global, aproximadamente 91,4 \% das matrículas, e quase todos os sistemas de ensino foram impulsionados a implementar soluções de práticas educacionais à 
distância. Esse cenário afetou todos os níveis de ensino, desde o pré-escolar, passando pela formação profissional e técnica, até o ensino superior.

No Brasil, algumas medidas foram adotadas por parte do Ministério da Educação, como a suspensão das atividades presenciais em cumprimento à portaria n. 343/2020 (alterada pelas Portarias n. 345/2020 e n. 395/2020) e a Medida Provisória (n. 934/2020), que autorizava atividades educacionais na modalidade remota, denominado de Ensino Remoto Emergencial - ERE. (BRASIL, 2020b; 2020c). As ações para a implantação do ERE ocorreram de maneira diversificada em instituições públicas e privadas, tendo como obrigatoriedade a transição imediata, sob o crivo de seus respectivos gestores no que tange à escolha dos métodos de trabalho. Esse processo foi permeado pelo sentimento de insegurança quanto ao ofício docente, dadas as novas habilidades exigidas na modalidade remota.

Diante desse contexto, o Grupo de Estudo Trabalho e Sociedade (GETs/UFPR) e a Rede de Estudos e Monitoramento Interdisciplinar da Reforma Trabalhista (REMIR) realizaram uma pesquisa em âmbito nacional, entre os dias 5 e 17 de maio de 2020, buscando levantar as condições de trabalho remoto no contexto da pandemia. As reflexões e os dados apresentados nesse artigo correspondem a um recorte da pesquisa intitulada "O trabalho remoto/home office no contexto da COVID-19"1, com filtro para os dados do setor educacional. De um total de 906 (novecentos e seis) participantes, 262 (duzentos e sessenta e dois) deles declararam pertencer ao setor educacional, atuantes em diversas atividades, a saber, docência, pesquisa, gestão, extensão e atuação técnica, em níveis de ensino distintos como fundamental, médio e superior. Por meio de análise correlacional, pretende-se refletir sobre as diferenças e similaridades das condições objetivas de trabalho dos docentes vinculados aos setores privado e público, participantes da referida pesquisa. A justificativa para realizar tal análise, a partir da divisão entre setor público e privado, tem como pressuposto que ambos os setores possuem características distintas, com especificidades e dinâmicas de funcionamento próprias.

Com relação à estrutura do artigo, apresenta, além da introdução, um panorama do setor educacional no contexto da pandemia, trazendo uma perspectiva global e especificidades locais, com vistas à realidade brasileira. Na sequência, o percurso metodológico evidencia o caminho que a pesquisa trilhou, dando ênfase aos métodos eleitos para análise dos dados empíricos. Ainda, na sessão de análise e discussão dos resultados, foram estabelecidos eixos de análise, buscando dar voz aos participantes da pesquisa por meio de uma análise correlacional entre os achados da esfera pública e privada.

\section{O cenário do setor educacional no contexto da pandemia COVID-19: do global ao local}

O contexto da pandemia reconfigurou o trabalho docente, sobretudo o conjunto de atividades pedagógicas desenvolvidas. Com as exigências da organização do trabalho para a modalidade remota, as instituições de ensino sugeriram que os docentes adaptassem e transpusessem suas atividades, antes estruturadas para a modalidade presencial, para um formato de interação digital. Independentemente do nível de ensino, o trânsito das atividades presenciais para o remoto demandou novas habilidades, sobretudo nos usos da tecnologia, de todos os envolvidos no processo de ensino e aprendizagem (BERNARDO; MAIA; BRIDI, 2020). Mesmo considerando

\footnotetext{
${ }^{1}$ A equipe da pesquisa foi composta por Fernanda Bohler, Fernanda Maia Landolf, Kelen Aparecida da Silva Bernardo, Alexandre Pilan Zanoni, Mariana Bettega Braunert, Giovana Uehara, Zélia Freiberger e coordenada por Maria Aparecida Bridi.
} 
que cada nível de ensino possui dinâmicas específicas, todos foram impactados fortemente pela adoção do ensino remoto como principal modalidade.

Ainda numa perspectiva em âmbito mundial, observa-se que, embora o ponto de partida para o setor educacional tenha sido o mesmo com as recomendações da Organização Mundial da Saúde (OMS), a saber, isolamento a paralisação imediata das atividades presenciais de ensino, as estratégias utilizadas foram diferentes em cada país, conforme podemos analisar no quadro a seguir, elaborado com base no documento da Organização Internacional do Trabalho (OIT) "A COVID- 19 e o setor da educação":

Quadro 1 - Estratégias adotadas na pandemia COVID -19 para a educação - 2020

\begin{tabular}{|l|l|}
\hline \multicolumn{1}{|c|}{ Países } & \multicolumn{1}{c|}{ Estratégias } \\
\hline Canadá, Quebec & $\begin{array}{l}\text { Suspensão dos acordos coletivos com os trabalhadores do setor educacional, visando } \\
\text { a permitir as adaptações necessárias para a realização do trabalho, considerando a } \\
\text { excepcionalidade da pandemia. }\end{array}$ \\
\hline Argentina & $\begin{array}{l}\text { Planejamento das modalidades de ensino à distância a partir de uma comissão conduzida } \\
\text { pelo Ministério da Educação. }\end{array}$ \\
\hline $\begin{array}{l}\text { Los Angeles, } \\
\text { Estados Unidos }\end{array}$ & $\begin{array}{l}\text { Acordo sindical visando à definição dos termos e condições de trabalho dos docentes, como } \\
\text { a flexibilidade de horários, à proteção contra a perda de remuneração ou de benefícios. } \\
\text { Quanto ao ensino e à aprendizagem, no contexto da pandemia, foi assegurada liberdade } \\
\text { na decisão quanto às modalidades de ensino. }\end{array}$ \\
\hline Finlândia & $\begin{array}{l}\text { Consulta ao sindicato vinculado aos trabalhadores da educação quanto à adoção das medidas } \\
\text { de emergência no ensino. Também foram implantados projetos, com o apoio da iniciativa } \\
\text { privada, em que foram oferecidos gratuitamente serviços à população como cursos e aulas } \\
\text { virtuais. }\end{array}$ \\
\hline Alemanha & $\begin{array}{l}\text { Reorganização do calendário escolar em algumas instituições e suspensão das atividades } \\
\text { presenciais em outras. }\end{array}$ \\
\hline $\begin{array}{l}\text { Reino Unido e } \\
\text { Austrália }\end{array}$ & $\begin{array}{l}\text { Abertura de escolas em localidades específicas para atendimento dos educandos filhos de } \\
\text { trabalhadores em atividades essenciais ou em situação de vulnerabilidade social. }\end{array}$ \\
\hline China & $\begin{array}{l}\text { Medidas públicas para a expansão do acesso à internet, assim como a oferta, por meio de } \\
\text { instituições educacionais, de cursos e disciplinas mediadas por plataformas digitais. }\end{array}$ \\
\hline Brasil & $\begin{array}{l}\text { Formação do Comitê Operativo de Emergência pelo da Educação para debater e definir } \\
\text { medidas contra a Covid-19. Edição de portarias que autorizavam e regulamentavam a oferta } \\
\text { do ensino remoto emergencial. }\end{array}$ \\
\hline
\end{tabular}

Fonte: Elaborado pelas autoras com base na OIT (2020); Gusso et al. (2020) e Brasil (2021)

No Brasil, a Portaria n. 343/2020 (alterada pelas Portarias n. 345/2020 e n. 395/2020) e a Medida Provisória (n. 934/2020), autorizaram a substituição de aulas presenciais por aulas em meios digitais e a flexibilização dos dias letivos, desde que mantida a carga horária mínima dos cursos. Com relação ao ensino remoto, Mancebo (2020) destaca que, embora tanto o ensino privado, quanto público tenham adotado a prática educacional pelas vias digitais, essa não é uma realidade nova, visto que, segundo a autora, as instituições privadas, em 2018, já detinham 24,3\% de suas matrículas à distância. Entretanto, o contexto epidêmico agravou o cenário "como noticiou a imprensa, a Laureate, que congrega várias faculdades privadas, além de utilizar robôs na correção de trabalhos sem o conhecimento dos alunos, demitiu mais de uma centena de professores, em maio de 2020" (MANCEBO, 2020, p. 10). Faz-se necessário demarcar que as condições e relações de trabalho dos docentes são distintas a depender da esfera a qual estão vinculados, 
seja pública ou privada; com isso também os impactos decorrentes da pandemia assumem especificidades diferenciadas.

No setor privado, medidas como redução de salários, jornadas oficiais de trabalho, demissões e ensalamentos (metodologias de agrupar diversas turmas em uma única sala virtual) emergiram como resultantes da realocação e estratégias frente ao contexto de crise, não só sanitária como também econômica, promovendo impactos nos rendimentos e nas condições de trabalho. Quanto ao setor público, a alteração da modalidade de trabalho presencial para a remota impôs a reorganização das atividades de ensino, pesquisa e extensão, bem como das demandas por parte da comunidade (genitores/as e discentes) a qualquer hora e em qualquer dia da semana, cenário que impulsionou aspectos da intensificação da jornada de trabalho. Em outra perspectiva, observa-se a existência de prejuízos no que tange à acessibilidade às plataformas digitais, principalmente por alunos e alunas pertencentes à maioria vulnerabilizada social e economicamente, gerando dificultadores para a oferta e o acesso à educação. Tais situações vêm atravessando e impactando as condições de trabalho dos docentes no referido setor.

O cenário acima atingiu todos os níveis de ensino, mesmo diante de suas devidas especificidades e diferenças. No ensino superior, por exemplo, percebe-se que a implantação do ERE acentuou uma crise que já antecedia o período pandêmico. Para Santos (2020, não paginado), os movimentos realizados pela universidade durante a pandemia aprofundaram o centralismo e a lógica burocrática, em que:

[...] cuidou-se pouco dos estudantes fora dos breves momentos online ou a braços com as exclusões que suposta cidadania digital provocou; os professores que dedicaram mais tempo aos estudantes fizeram-no por iniciativa própria e espírito de missão; descuidou-se totalmente a situação dos professores, enfrentando alterações na vida familiar, recorrendo a tecnologias de ensino com que a maioria estava pouco familiarizada, com uma carga burocrática imensa, com a vontade de inovar, quase por necessidade ante os desafios da pandemia, mas barrados pelo muro de burocracia. Em suma, a pandemia veio agravar as tendências de degradação da universidade que já se vinham a notar há muito. (SANTOS, 2020, n.p.).

Esse movimento de transposição do ensino presencial para o remoto, embora tenha sido iniciado com as medidas provisórias e portarias supracitadas em âmbito nacional, foi adotado individualmente por instituições públicas e privadas, com planos de ação específicos para a realidade de cada instituição, seja por meio de acordos coletivos, ajustes de carga horária, treinamentos particularizados para o ofício docente na modalidade remota, ou outras ações inerentes à aplicabilidade e implantação do ensino remoto emergencial.

\section{Ensino remoto emergencial e home office no setor educacional: alguns pressupostos}

A Educação à Distância (EaD) possui legislação própria e se estrutura de maneira específica para sua aplicabilidade. Com o cenário da pandemia da COVID-19 em 2020/2021, trabalhar à distância, em home office, foi a solução imediata orientada por órgãos internacionais para evitar a disseminação do vírus e incentivar a preservação da vida. É nesse ponto que observamos o primeiro conflito que se instaurou nesse contexto: a compreensão de que tipo de trabalho seria realizado no espaço doméstico, visto que o $\mathrm{EaD}$ se difere, em vários aspectos, do ensino remoto emergencial (ERE), salvo a similaridade na base fundamental que une essas duas realidades, entenda-se, os usos das Tecnologias da Informação e Comunicação (TICs). 
Enquanto o EaD pressupõe uma infraestrutura preconcebida para sua realização, demandando técnicas específicas de desenho de curso, de tecnologias instrucionais, de métodos de comunicação eletrônica, bem como arranjos administrativos e organizacionais especiais (PEREIRA; MORAES, 2009), o ERE caracteriza-se por uma opção desestruturada, haja vista que a sua implementação se deu em caráter de urgência, sem momentos de planejamento, organização e preparação/capacitação prévia dos trabalhadores envolvidos com o processo dessa modalidade.

Embora o EaD fosse uma modalidade já difundida e muito utilizada por diversas instituições de ensino, sobretudo do setor privado, o trabalho docente na modalidade presencial, segundo Mancebo (2020), sempre englobou o ensino, a pesquisa e a extensão, bem como um crescente número de atividades administrativas, predominantemente exercidas in loco; entretanto, no cenário pandêmico, foi levado por inteiro para as casas dos professores. Ainda segundo a autora, nesse complexo de atividades, o ensino remoto, na modalidade home office, merece um destaque, pois se alastrou juntamente com a pandemia, tanto no ensino privado, como no público (MANCEBO, 2021).

Necessário se faz demarcar que as especificidades que o trabalho remoto vem assumindo no contexto da pandemia são distintas do trabalho remoto realizado anteriormente. Entretanto, as tramas das complexas e desiguais relações e condições de trabalho engendradas no capitalismo financeirizado estão presentes, mesmo que assumindo novas roupagens. As mudanças no mundo do trabalho, nos termos de Antunes (2008), afetam, mesmo que em intensidades e proporcionalidades específicas, todas as pessoas que sobrevivem da venda da sua forma de trabalho. O contexto pandêmico escancara a "ampliação do empobrecimento e dos níveis de miséria em amplas parcelas e segmentos dessa classe”, evidenciando as relações de exploração do trabalho precarizado ou "o que é ainda mais brutal, pelo flagelo do desemprego, subemprego e da informalidade, fenômenos explosivos e que têm uma dimensão global." (ANTUNES, 2021, p. 112). Assim, análises das condições do trabalho remoto dos docentes no contexto da pandemia são realizadas tendo como pressupostos teórico-metodológicos os processos de precarização e intensificação do trabalho que vêm ocorrendo nas últimas décadas.

Ao olharmos para as possibilidades da modalidade de trabalho em home office, entendendo que essa já é uma realidade para milhões de trabalhadores pelo mundo e que ganhou proeminência na crise sanitária, damos destaque ao fato de ser um trabalho realizado exclusivamente no domicílio do trabalhador. É a partir desse lugar, da casa, e dessa modalidade (ERE), que realizaremos nossas análises. Oliveira (2017) explica que as pesquisas sobre teletrabalho contemplam diferentes nomenclaturas tais como "trabalho remoto, trabalho virtual, telework, telecommuting - para designar o que estamos tratando por trabalho em home office, o qual refere-se às atividades de trabalho realizadas, geralmente, a partir de casa e mediadas por tecnologias informacionais". (OLIVEIRA, 2017, p. 58). A perspectiva teórica aqui adotada é de que o trabalho remoto realizado no contexto pandêmico se distingue dos praticados anteriormente, assumindo especificidades que são determinadas pelo caráter provisório e emergencial do estado de calamidade pública, imprimindo novas característica na organização do trabalho que, anteriormente era realizado presencialmente nas instituições educacionais (BERNARDO; MAIA; BRIDI, 2020).

A adoção do trabalho remoto tem recepções dicotômicas, tendo defensores e críticos recebendo elogios e apresentando resistências. Os defensores argumentam que essa modalidade "permite melhoria na gestão dos trabalhadores, maior agilidade quanto às decisões, maior controle dos dados e informações históricas, dada a facilidade de seu armazenamento e acesso a qualquer tempo e lugar". Já os críticos ressaltam a dificuldade em se estabelecer limites quanto ao "tempo de trabalho, uma vez que o trabalhador se mantém 24 horas conectado com a empresa 
por meio das várias plataformas ou aplicativos" (BRIDI, 2020, p. 174). A partir do uso das tecnologias informacionais, Oliveira (2017) alerta que seria fundamental um respaldo jurídico que acompanhasse as mudanças que constituem essa modalidade de trabalho, sobretudo em função dos usos do tempo de trabalho e de não trabalho, realidade que se acentua no período pandêmico.

Sobre a autonomia do trabalho em modalidades como a remota, Oliveira (2017) ressalta que ela visivelmente trouxe impactos no que tange à organização, gestão e realização do trabalho, principalmente na relação tempo e espaço de labor, pois a partir das plataformas informacionais, softwares institucionais e dispositivos móveis, o trabalhador pode ser localizado e contactado a qualquer momento. Inclusive, esse é um dos achados da pesquisa quanto às dificuldades do trabalho remoto, em que os docentes afirmam não conseguirem se desconectar, pois recebem demandas a todo momento.

Para Hodges (2020) a mudança da instrução on-line permitiu a flexibilidade de ensino e aprendizagem em qualquer lugar e a qualquer hora, e a velocidade com a qual essa mudança ocorreu é inédita. O autor aponta ainda que, embora algumas instituições de ensino tenham equipes de suporte para auxílio da gestão educacional no que tange ao ensino e aprendizagem dos usos das ferramentas tecnológicas, geralmente apoiavam um pequeno grupo de professores interessados na modalidade à distância. No cenário pandêmico, a necessidade passa a ser de todos os docentes e, dessa forma, as equipes de apoio não são suficientes para dar suporte técnico ao contingente de demandas, podendo, ao nosso ver, caracterizar um fator de mais trabalho para esses profissionais.

Ainda, a conjuntura conformada no trabalho remoto no cenário epidêmico, fez emergir a necessidade de regulações quanto às condições de trabalho realizado remotamente, como, por exemplo, o direito à desconexão, à limitação da carga horária e às condições ergonômicas que o trabalho docente demanda. É importante demarcar que a regulação das relações de trabalho na modalidade remota na educação é uma necessidade que se coloca, visto que o ERE perdura há mais de um ano e, ao menos em um cenário próximo, não se afigura uma total retomada das atividades presenciais nas instituições educacionais, sendo que o ensino híbrido, modalidade em que parte das atividades são remotas e parte presenciais, é uma realidade cada vez mais praticada.

Em termos de regulação do trabalho remoto docente, a Nota Técnica - GT COVID-19 n. 11/2020 do Ministério Público do Trabalho (MPT) estabelece diretrizes para os estabelecimentos de ensino, com o intuito de garantir a "proteção da saúde e demais direitos fundamentais de professoras e professores que exercerem as suas atividades laborais por meio de plataformas virtuais e/ou em home office", em decorrência da pandemia. Assim, a referida portaria orienta que seja praticado, "preferencialmente por meio de negociação coletiva, um acordo coletivo, e por contrato de trabalho aditivo por escrito", estabelecendo os termos e as condições em que o trabalho será desenvolvido no meio remoto, indicando o prazo, a forma, "a responsabilidade pela aquisição, manutenção ou fornecimento dos equipamentos tecnológicos e da infraestrutura do trabalho remoto, bem como o reembolso de eventuais despesas a cargo do trabalhador. (MPT, 2020, p. 3-4)

\section{Metodologia}

A escolha do caminho epistemológico foi critério fundamental para delinear o escopo desta pesquisa. Procurou-se, por meio de uma pesquisa de natureza aplicada e exploratória, com abordagem qualitativa e quantitativa, levantar as condições objetivas de trabalho de professores de 
instituições públicas e privadas, a fim de correlacionar suas similitudes e lançar luz às diferenças quanto à organização do trabalho e infraestrutura para atuação no ERE.

Pautamo-nos na compreensão de Minayo $(2014$, p. 2) sobre a validade da combinação de métodos qualitativos com quantitativos, uma vez que possibilita a complementaridade na pesquisa, respeitando sua natureza diversa, pois "uma trata da magnitude dos fenômenos, a outra, da sua intensidade. Uma busca aquilo que se repete e pode ser tratado em sua homogeneidade, a outra, as singularidades e os significados".

Os dados empíricos são de uma pesquisa mais ampla intitulada "O trabalho remoto/home office no contexto da COVID-19", realizada por pesquisadores do Grupo de Estudo Trabalho e Sociedade (GETs/UFPR) e da Rede de Estudos e Monitoramento Interdisciplinar da Reforma Trabalhista (REMIR). No que se refere à população da pesquisa, dos 963 respondentes, 262 declararam pertencer ao setor educacional, recorte esse utilizado para a realização do presente artigo. Dos 262 participantes, 177 são da esfera pública e 85 da esfera privada. O instrumento de pesquisa aplicado foi um questionário desenvolvido e disponibilizado pela Plataforma Google, com 37 perguntas, sendo duas delas abertas. O período de aplicação foi entre os dias 5 e 17 de maio de 2020. Com relação ao tipo de amostragem, caracterizou-se por não-probabilística, por acessibilidade e conveniência, em função da seleção dos participantes ter ocorrido por adesão a partir da divulgação em redes sociais e redes de pesquisa, sendo que o único critério de participação era ter iniciado o trabalho remoto em decorrência da pandemia da COVID-19. Com relação à localidade dos participantes da pesquisa, entre os principais municípios citados pelos 262 respondentes destaca-se que $43,8 \%$ dos trabalhadores na modalidade remota do setor de educação atuam na cidade de Curitiba, enquanto Campina Grande corresponde a 3,4\%, seguida de Toledo com 3\%, Ponta Grossa com 2,6\% e Campinas com 2,2\% (MAIA, BERNARDO, 2020).

Analisamos as atividades que compõem o ofício docente na modalidade remota, a saber, o ensino, pesquisa, extensão, gestão e atividades técnicas de laboratório, assim como qual a infraestrutura disponível para o docente, procurando perceber diferenças ou similitudes a respeito da organização e configuração do trabalho docente em ambas as esferas (público e privada). As análises foram realizadas pela perspectiva correlacional, ou seja, considerando a impossibilidade de analisar realidades distintas, pois possibilita estabelecer relações/conexões entre as variáveis comuns ao trabalho docente remoto nas distintas instituições, sem que isso ocasione o apagamento de suas especificidades.

Para a organização e análise das questões abertas dos questionários, optou-se por utilizar o software IRAMUTEQ. Por meio da análise de similitude de palavras por HALO, é possível a identificação das ocorrências de palavras e seus resultados, assim como as suas conexões. Vasconcelos (2018) explica que a análise de similitude evidencia "os núcleos que foram encontrados dentro do corpus textual, proporciona identificar os tópicos mais relevantes para serem abordados e qual sua representatividade" nas informações coletadas. Então, ao centro, estão os temas de destaque e, em seu entorno orbitam os temas subsidiários à pesquisa (VASCONCELOS, 2018, p. 11).

As imagens geradas pelo software IRAMUTEQ nos permitem a realização de observação das palavras utilizadas pelos participantes da pesquisa, com relação às percepções do trabalho remoto efetuados durante a pandemia, bem como as conexões das expressões utilizadas para manifestar o entendimento do próprio trabalho nessa modalidade. Ou seja, no núcleo central das figuras estão as palavras de maior expressão para o grupo pesquisado, enquanto no seu entorno estão as suas conexões. 
Para a categorização das questões respondidas pelos participantes vinculados ao setor educacional, foram estabelecidos eixos de análise, com o intuito de identificar correlações e diferenças das condições objetivas de trabalho nas instituições públicas e privadas.

Quadro 2 - Eixo de análise do trabalho docente na modalidade ERE em instituições públicas e privadas

\begin{tabular}{|l|l|}
\hline \multicolumn{1}{|c|}{ Eixo } & \multicolumn{1}{c|}{ Descritivo da Análise } \\
\hline Configurações do Trabalho & Análise da organização do trabalho (contrato, carga horária). \\
\hline Infraestrutura para o trabalho & Análise da ergonomia, internet, plataformas digitais, equipamentos. \\
\hline Intensidade & Análise das metas de produtivismo, critérios e alterações \\
\hline $\begin{array}{l}\text { Percepções do Ensino Remoto } \\
\text { Emergencial }\end{array}$ & Análise da avaliação do trabalho remoto pelos participantes. \\
\hline
\end{tabular}

Fonte: Elaborado pelas autoras

\section{Desenvolvimento e análise dos dados}

Ao realizar uma análise correlacional sobre as condições objetivas de trabalho da categoria docente, um aspecto importante foi identificar quais as modalidades de vínculos que os participantes da pesquisa possuíam com cada setor. Foram identificadas diversas modalidades, desde as formas protegidas de trabalho, como os estatutários e celetistas, quanto formas de admissão flexíveis, como autônomos, estágios, bolsistas, e contratos por tempo determinado, microempreendedor, como é possível constatar na tabela a seguir:

Tabela 1 - Comparativo das modalidades de vínculos no setor público e privado

\begin{tabular}{|c|c|c|}
\hline Setor & \multirow{2}{*}{ Valor absoluto } & \multirow{2}{*}{$\%$} \\
\hline Setor Público & & \\
\hline Estatutário & 133 & $75,1 \%$ \\
\hline Contrato por tempo determinado & 29 & $16,4 \%$ \\
\hline CLT & 8 & $4,5 \%$ \\
\hline Cargo em comissão & 2 & $1,1 \%$ \\
\hline Bolsista & 3 & $1,7 \%$ \\
\hline Autônomo & 2 & $1,1 \%$ \\
\hline \multicolumn{3}{|c|}{ Setor privado } \\
\hline CLT & 74 & $87,1 \%$ \\
\hline Contrato por tempo determinado & 5 & $5,9 \%$ \\
\hline Autônomo & 4 & $4,7 \%$ \\
\hline Estagiário & 1 & $1,2 \%$ \\
\hline MEI & 1 & $1,2 \%$ \\
\hline
\end{tabular}

Fonte: Elaborado pelas autoras com base no Banco de dados setor educacional (2020)

Os dados evidenciam que 75\% dos participantes vinculados ao setor público são estatutários, atendendo ao que preconiza o artigo 37 da Constituição Federal de 1988. Os contratos temporários 
somam $16 \%$ do total e os celetistas 4,5\%. As demais modalidades identificadas representam percentuais relativamente baixos, a saber, cargos em comissão (1\%), bolsista (1,7\%) e autônomo (1\%). Já no setor privado, $87 \%$ são celetistas, 5,9\% possuem contratos temporários, 4,7\% são autônomos enquanto a modalidade de estágio e Microempreendedor Individual (MEI) representa 1,2\% cada. Mesmo considerando as disparidades do volume de participantes referente a cada setor, quando analisamos percentualmente, verificamos que há maior percentual de vínculos temporários no setor público que no privado.

A contratação temporária no setor público, segundo a lei n. 6.019 de 03 de janeiro de 1974, difere da contratação temporária praticada no setor privado. Considera-se trabalho temporário no setor privado "aquele prestado por pessoa física contratada por uma empresa de trabalho temporário que a coloca à disposição de uma empresa tomadora de serviços, para atender à necessidade de substituição transitória de pessoal permanente ou à demanda complementar de serviços" (BRASIL, 1974). Assim, há uma intermediação da mão de obra por uma empresa, o que não ocorre no setor público. A contratação temporária na administração pública se dá via contrato celebrado diretamente com o trabalhador, sendo regulado por leis específicas que, a priori, visam à contratação emergencial para atender às demandas urgentes, até que se realize concurso público. São trabalhadores temporários, com contrato por tempo determinado e que não acessam os direitos dos servidores públicos estatutários e não são celetistas.

No campo da educação, Bernardo (2020), ao analisar as condições e relações de trabalho dos docentes temporários atuantes no ensino superior público, evidencia um aumento expressivo dessa forma de contratação nos últimos anos. À condição contratual de temporários, cuja insegurança e instabilidade no trabalho na renda são constantes, soma-se "a exclusão de um conjunto de direitos e garantias, quando comparados aos professores efetivos, condições de trabalho desiguais e relacionamentos assimétricos e heteronômicos com os pares", relação que emerge como aspecto problemático (BERNARDO, 2020, p. 297).

Ao analisarmos as modalidades de vínculo em ambos os setores, também é importante atentarmos para as alterações de carga horária de trabalho e do rendimento, autorizadas pela Medida Provisória n. 936, convertida na Lei 14.120/2020, no caso do setor educacional privado, devido ao contexto da pandemia. Considerando que ao transpor as atividades educacionais presenciais para a modalidade remota o trabalho sofreu alterações e continuou sendo realizado, em função desse cenário buscamos identificar se ocorreram modificações na composição da carga horária e dos rendimentos para os participantes da pesquisa.

Em ambos os setores, a maioria dos docentes não sofreu alterações na carga horária e nem nos rendimentos, sendo que, no setor público, $86 \%$, e, no privado, $76 \%$ afirmaram não ter ocorrido mudanças nesses dois aspectos. A redução de carga horária de trabalho e de salário foi identificada somente no setor privado, representando um percentual de $12 \%$ dos respondentes vinculados ao referido setor. As alterações como redução de salário sem alteração na carga horária de trabalho (privado 7\%, e público 5\%) e redução somente de carga horária de trabalho, sem redução de salário (privado 5\%, e público 9\%) foram identificadas nos dois setores com valores próximos. A partir dos dados, é possível inferir que o fator diferencial está no fato de que o setor público manteve um percentual maior, quando comparado com o setor privado, de trabalhadores sem alterações no salário como a mesma carga horária. Se observamos que os estatutários representam $75 \%$ dos participantes vinculados ao setor público, concluímos que outros vínculos também foram beneficiados com a manutenção das mesmas relações de trabalho praticadas presencialmente. 
Considerando a provisoriedade e a urgência com que o trabalho remoto foi adotado no contexto da pandemia, no início do ano de 2020, procuramos identificar como se deu a organização das questões práticas do cotidiano do trabalho, como o acesso aos recursos necessários para o ofício docente. Diante da necessidade da transposição das atividades presenciais para o remoto, perguntamos como os trabalhadores avaliam suas condições de trabalho quanto à ergonomia. Identificamos que no setor privado, $33 \%$ entendem que são excelentes, tendo à disposição mobiliário e espaços adequados, enquanto no setor público esse percentual é mais alto, representando 41\% dos respondentes; $59 \%$ dos docentes atuantes no setor privado avaliam sua condição como razoável, pois não dispõem de um espaço específico para realização do trabalho, mas havia mesa e cadeira. Essa situação também é verdade para 51\% dos vinculados ao setor público. Por fim, $8 \%$ em ambos os setores declara que suas condições de trabalho são péssimas, pois não há espaço, cadeira e nem mesa para realizarem seu trabalho.

A partir da realidade delineada pelos dados, temos que mais da metade dos docentes realizavam suas atividades em condições inapropriadas quanto à ergonomia, o que pode impactar tanto na saúde quanto na qualidade do trabalho realizado. Esse fato é relevante se considerarmos as especificidades do ofício docente, que pode ser afetado com maior ou menor intensidade a depender das condições ergonômicas, pois é composto por atividades que demandam condições múltiplas como silêncio, concentração, espaços arejados, iluminados, com mobílias apropriadas. Todos esses aspectos ganham destaque quando se trata do trabalho remoto no contexto da pandemia, no qual o ERE é mediado essencialmente pelas TIC'S, exigindo dos professores e professoras horas de trabalho na frente das telas dos computadores e smartphones, tendo seus lares como ambiente de trabalho sem nenhum controle das condições mínimas para que tais atividades aconteçam.

A partir desse contexto, questionamos se os trabalhadores e trabalhadoras receberam as ferramentas/materiais necessários para a execução do trabalho remoto. Ainda, se há diferenças significativas entre o setor privado e público. Com base no banco de dados, verificamos diferenciações entre os setores, pois os respondentes que indicaram ter recebido das instituições as ferramentas necessárias para o trabalho remoto representam 33\% no setor público, contra $60 \%$ no privado. As ferramentas mais disponibilizadas, em ambos os setores, foram software/plataforma (41\% no público e $55 \%$ no privado) e computadores (20\% no público e $15 \%$ no privado). Para o conjunto de participantes da pesquisa, inferimos que os docentes vinculados ao setor privado receberam mais suporte na disponibilização das ferramentas, quando comparados aos trabalhadores do setor público, pois $67 \%$ dos vinculados ao último afirmaram não ter recebido auxílio da instituição para a realização do trabalho remoto; esse mesmo aspecto tem um percentual, no setor privado, de $40 \%$.

Se um contingente significativo de docentes não recebeu auxílio para a adaptação do trabalho presencial à modalidade remota, buscamos identificar se houve a necessidade de investimentos pessoais para tornar possível a continuidade do trabalho. O setor privado aparece com percentual maior de respondentes que necessitaram custear os insumos para a realização do trabalho, representando $60 \%$ do conjunto vinculado a esse setor, enquanto no setor público esse percentual foi de 49\%. A Consolidação das Leis do Trabalho (CLT), ao regulamentar o tema sobre os custos do trabalho, estabelece que empregado e empregador devem acordar sobre os custos relacionados ao trabalho em regime de teletrabalho (luz, internet, telefone, entre outros itens necessários): 
Art. 75-D. As disposições relativas à responsabilidade pela aquisição, manutenção ou fornecimento dos equipamentos tecnológicos e da infraestrutura necessária e adequada à prestação do trabalho remoto, bem como ao reembolso de despesas arcadas pelo empregado, serão previstas em contrato escrito. (BRASIL, 1949),

Considerando a urgência da transição do trabalho presencial para o remoto, muitos docentes acabaram arcando com as despesas demandadas por esse processo, visto que não havia previsão em contrato para o reembolso de tais despesas. Para os participantes da presente pesquisa, um percentual importante precisou arcar com tais custos, mesmo diante do fato de que quando a pesquisa foi realizada, a Medida Provisória n. 927/20 - que flexibilizou a organização do trabalho presencial para o remoto durante o estado de calamidade pública, também previa acordo prévio quanto aos custos. Mesmo estando em condições que permitiam ao empregador custear materiais para o empregado esses trabalhadores não receberam auxílio das instituições empregadoras para se adaptarem à nova rotina. São gastos que podem impactar de formas mais ou menos significativas os orçamentos de tais trabalhadores, quando consideramos o contexto de crise socioeconômica acentuada pela crise sanitária.

No setor público, a Instrução Normativa n. 65/2020, que estabelece critérios, orientações e procedimentos gerais a serem observados pelos órgãos e entidades da administração pública federal para a implementação de programa de gestão, traz que:

Art. 23. Quando estiver em teletrabalho, caberá ao participante providenciar as estruturas física e tecnológica necessárias, mediante a utilização de equipamentos e mobiliários adequados e ergonômicos, assumindo, inclusive, os custos referentes à conexão à internet, à energia elétrica e ao telefone, entre outras despesas decorrentes do exercício de suas atribuições. (BRASIL, 2020).

Em 2020 as legislações apresentavam regulações quanto ao teletrabalho e não faziam menção ao trabalho remoto; nesses termos, a responsabilidade pelos gastos com o trabalho realizado distante do espaço físico da instituição empregadora não estava claramente regulamentada, e a falta de definição da incumbência quanto à aquisição de equipamentos e despesas pode trazer prejuízos para os trabalhadores. Importante demarcar que está em tramitação o Projeto de Lei $5.581 / 2020$, que pretende regular as condições do teletrabalho, por exemplo, as condições de saúde física e mental dos/as teletrabalhadores/as (BRASIL, 2020).

Buscando estimar os custos de se trabalhar em casa, o Instituto Brasileiro de Economia da Fundação Getúlio Vargas (FGV-IBRE) criou a "cesta home office", indicando que o gasto com o trabalho remoto pode representar um acréscimo de até $25 \%$ nas despesas com internet, água, alimentação e energia, entre outros. A complexidade dessa discussão extrapola o escopo em foco, qual seja, a análise relacional das condições objetivas de trabalho remoto dos docentes vinculados ao setor público e privado, uma vez que não há como desconsiderar que a pandemia impulsionou mudanças na forma de trabalho de milhões de trabalhadores, da mesma forma que as realocações e experiências resultantes desse processo, provavelmente permanecerão mesmo em um cenário pós-pandemia. 


\section{Metas, produtivismo e percepções do trabalho remoto: correlação entre setor público e privado}

Nesse cenário de alteração da organização do trabalho dos professores, a pesquisa procurou identificar, quanto à existência de critérios de metas, se os participantes perceberam alguma diferença no período do exercício da modalidade remota. Com relação à esfera pública, 45,8\% afirmam ter metas de produção na modalidade ERE, enquanto 54,2\% disseram o contrário. $\mathrm{Na}$ esfera privada, observa-se que 58,8\% receberam metas para cumprimento no período especial, e 41,2\% dos participantes não tiveram metas ou sua ampliação estipulada para esse período. Nesse mesmo tópico, os participantes foram questionados com relação às alterações das metas. Vejamos os resultados a seguir:

Tabela 2 - critérios de metas de produtividade - setor público e privado

\begin{tabular}{l|c|c}
\hline \multicolumn{1}{c|}{ Indicador } & Público & Privado \\
\hline Não houve alteração quanto à meta de produtividade & $21,5 \%$ & $29,4 \%$ \\
\hline Diminuiu a meta de produtividade & $10,2 \%$ & $7,1 \%$ \\
\hline Aumentou a meta de produtividade & $17,5 \%$ & $24,7 \%$ \\
\hline Não se aplica ao meu trabalho & $51 \%$ & $38,8 \%$ \\
\hline
\end{tabular}

Fonte: Elaborado pelas autoras com base no Banco de dados setor educacional (2020)

Em análise correlacional entre o setor público e privado, observou-se que o critério de metas não se aplica para $38,8 \%$ do setor privado e $51 \%$ do setor público. As metas não se alteram para $21,5 \%$ dos docentes vinculados ao setor público e $29,4 \%$ ao privado. A diminuição das metas de produtividade aparece em 7,1\% no setor público e 10,2\% no setor privado. Ocorreu aumento das metas de produtividade para $24,7 \%$ dos docentes vinculados ao setor privado e $17,5 \%$ do setor público. Esses dados revelam que o trabalho docente está sendo permeado por critérios de metas de produção, uma vez que $45,8 \%$ na esfera pública e $58,8 \%$ na privada dos docentes têm suas atividades pautadas em metas que precisam ser cumpridas. 0 destaque entre os setores está no privado, no qual a presença de critérios de metas é mais expressiva.

Os participantes puderam expressar em questão aberta suas impressões a respeito do trabalho remoto, e perceberam que as metas intensificaram suas rotinas de trabalho, como pode-se observar no fragmento da fala do Respondente 13:

Acredito que o volume de trabalho aumentou e a cobrança por parte da chefia também. Muitos alunos disparando um número enorme de e-mails, whatsapp, com muitas dúvidas principalmente a execução de trabalhos acadêmicos, ABNT. Gravação de aulas, aulas ao vivo... Monitoramento dos alunos. (Respondente 13, pesquisa de campo, 2020)

Isso nos leva a questionar se o modelo remoto afetou o ritmo de trabalho. Como podemos verificar no gráfico a seguir, a mudança do trabalho presencial para o remoto impactou na sua intensidade, pois $78 \%$ dos respondentes no setor privado e $51 \%$ no público afirmaram que o ritmo de trabalho ficou mais acelerado. 
Gráfico 1 - Alteração do ritmo de trabalho no trânsito presencial para a modalidade remota - setor público e privado

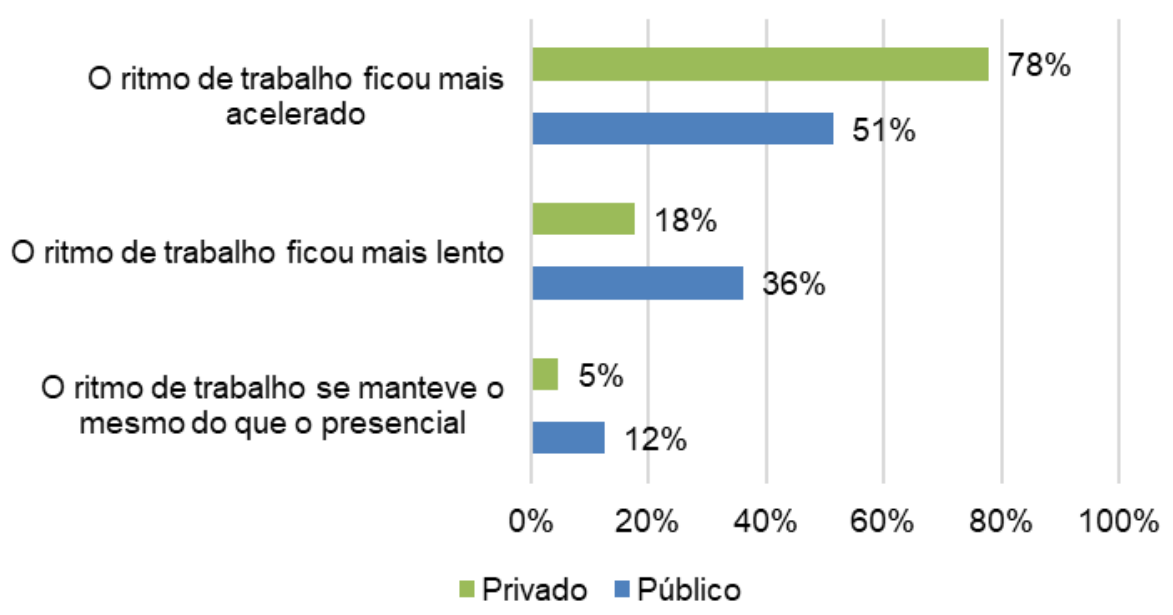

Fonte: Elaborado pelas autoras com base no Banco de dados setor educacional (2020)

Ambos os setores foram impactados de formas distintas, sendo que os docentes vinculados ao setor privado sentiram em maior proporcionalidade o aumento no ritmo do trabalho, passando a trabalhar mais dias na semana. O quadro de intensificação, para Dal Rosso (2008) estão vinculados ao ritmo e a velocidade com a qual o trabalhador desenvolve suas atividades. A partir dos dados da pesquisa, verifica-se que ocorreu aumento no ritmo de trabalho ao desempenhar suas atividades remotamente. Assim, acredita-se haver um processo de intensificação, que, segundo Dal Rosso (2008, p. 46) trata-se de "exigir mais trabalhos e resultados superiores no mesmo espaço de tempo". Assim, os usos conscientes da tecnologia, de maneira exacerbada, a partir do ensino remoto, intensificam o trabalho docente, visto que as plataformas virtuais os mantêm conectados em tempo integral.

Em estudo que antecede a pandemia e trata dos impactos da modalidade home office para o trabalhador, Oliveira (2017, p. 102), aponta que:

Trabalhar em casa, na modalidade de home office, tem se mostrado um instrumento de intensificação do trabalho para os trabalhadores digitais. Se, de um lado, a ausência de deslocamento é discursivamente apontada como fator redutor do estresse no trabalho, por outro, a própria atividade de trabalho é por "natureza" geradora de estresse

Na realidade dos participantes da pesquisa, essa dualidade supracitada também é identificada, pois a partir dos conteúdos das respostas observam-se aspectos positivos como a eliminação de deslocamentos desgastantes da rotina diária e, principalmente, a proteção contra a exposição ao vírus da COVID-19. Mas, ao mesmo tempo, o processo de trabalho torna-se mais desgastante, visto que o contato, as relações, as decisões são mediadas pelas TICs, tornando o processo moroso e demandando concentração e habilidades diferentes quando comparadas ao trabalho presencial. No contexto da pesquisa, trabalhar remotamente também tem significado trabalhar mais dias da semana, como podemos observar no gráfico a seguir: 
Gráfico 2 - Comparativo de dias trabalhados na semana presencial e remotamente setor privado e público

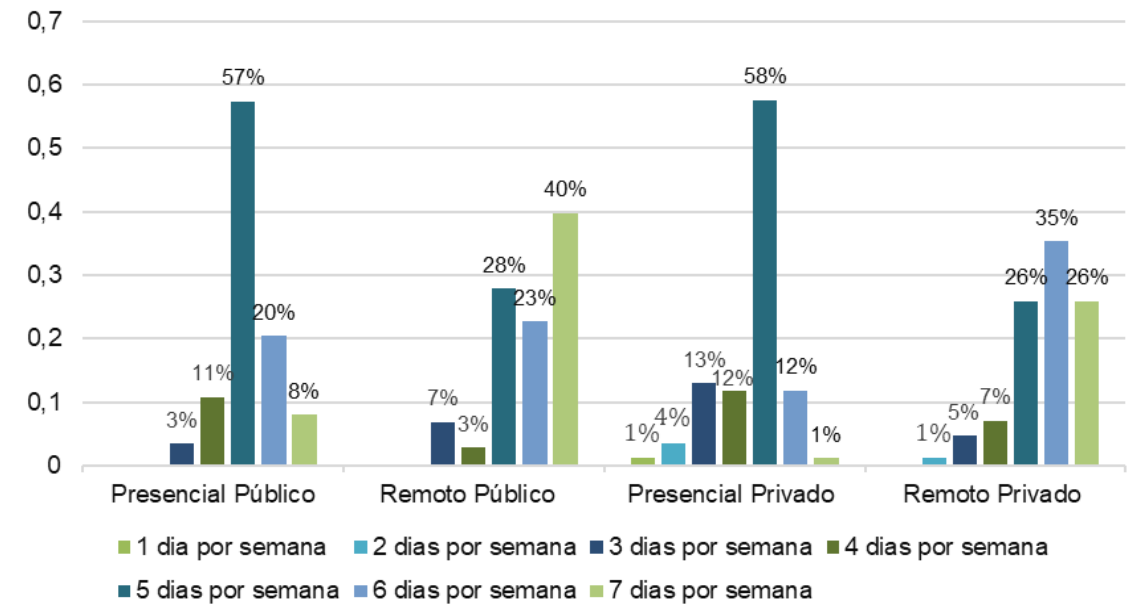

Fonte: Elaborado pelas autoras com base no Banco de dados setor educacional (2020)

Considerando que a maioria dos docentes declararam que seu ritmo de trabalho se intensificou na modalidade remota, quando comparamos a quantidade de dias trabalhados na semana presencialmente, antes da pandemia, e, na pandemia, remotamente, podemos identificar que o aumento no ritmo também resultou em mais dias de trabalho. Os percentuais dos que trabalhavam cinco (5) dias na semana, antes da pandemia, eram significativamente próximos em ambos os setores, $57 \%$ no público e $58 \%$ no privado. Quando passa para a modalidade remota, esse percentual cai para $28 \%$ no público e $26 \%$ no privado. O aumento nos dias trabalhados ocorre em ambos os setores, porém com comportamentos distintos. Para os docentes com vínculo com o setor privado, os aumentos mais expressivos foram nos percentuais dos que trabalhavam seis (6) dias semanais, que saiu de $12 \%$ e saltou para $35 \%$, os com labor sete (7) dias da semana eram $1 \%$, número que passou para $26 \%$. Já para os com vínculo na administração pública, a alteração mais significativa foi no aumento dos que trabalhavam sete (7) dias na semana, passando de $8 \%$ antes para $40 \%$ durante a pandemia. Esse cenário revela que uma das armadilhas que o home office apresenta, para além da extensão das jornadas diárias, é o aumento de dias trabalhados na semana. Outra estudiosa da modalidade home office, Castro (2013) analisa que:

Além do uso das ferramentas de tecnologia para prolongamento das jornadas de trabalho e embaçamento das fronteiras do tempo de lazer e de trabalho, o entrelaçamento entre os espaços da vida privada e do escritório e demais locais de trabalho tem como referência máxima a prática do Home Office. (CASTRO, 2013, p. 126)

Nesse contexto, em análise do trabalho remoto dos professores em home office, observa-se uma sobrecarga de trabalho, pressionada por jornadas laborativas intensas e longas, resultando em extrapolação da carga horária formalmente prevista em seus contratos. Estudos já demonstraram que o trabalho docente, dado a sua especificidade, mesmo antes da pandemia, já não era cercado por uma carga horária bem delimitada, como prevista nos contratos de trabalho (BERNARDO, 2020; MAIA, 2014). Com a adoção do trabalho remoto, potencializado pelo contexto pandêmico, essa característica se acentua expressivamente, como mostram os dados da presente pesquisa, fato que coloca em xeque a conquista da limitação da jornada de trabalho diária, não só para os trabalhadores da educação, mas para a classe trabalhadora com um todo. 
Os aspectos conjunturais envolvidos na transposição do trabalho presencial para o remoto afetaram as condições de trabalho dos docentes. É fato que, do conjunto de participantes da pesquisa, 75\% do setor público e $66 \%$ do privado afirmaram que encontraram dificuldades para realização de suas atividades na modalidade remota. Entre as dificuldades mais recorrentes indicadas em ambos os setores estão o maior tempo demandado para realização das atividades usuais; interrupções frequentes e recebimento de demandas há qualquer hora e dia da semana.

A partir das falas dos respondentes, foi possível levantar as principais percepções a respeito da atuação na modalidade remota e, para análise de conteúdo e compilação dessas informações, optamos pela utilização do software IRAMUTEQ conforme linhas que seguem.

\section{Percepções do ensino remoto emergencial}

Com vistas às análises das percepções dos docentes a respeito do trabalho remoto nos setores público e privado, procurou-se, por meio da análise de similitude, com o recurso do software IRAMUTEQ, criar imagens que permitissem visualizar as conexões recorrentes nas falas dos participantes da pesquisa. A Figura 1 apresenta as percepções dos docentes vinculados à esfera privada, elaborada a partir da resposta aberta da questão 37, que procurou captar a experiência do trabalho remoto, seus principais problemas e vantagens, assim como outros comentários que o/a docente tivesse interesse em registrar. Vejamos:

Figura 1 - Análise de similitude das percepções docentes do trabalho remoto na esfera privada pelo software IRAMUTEQ

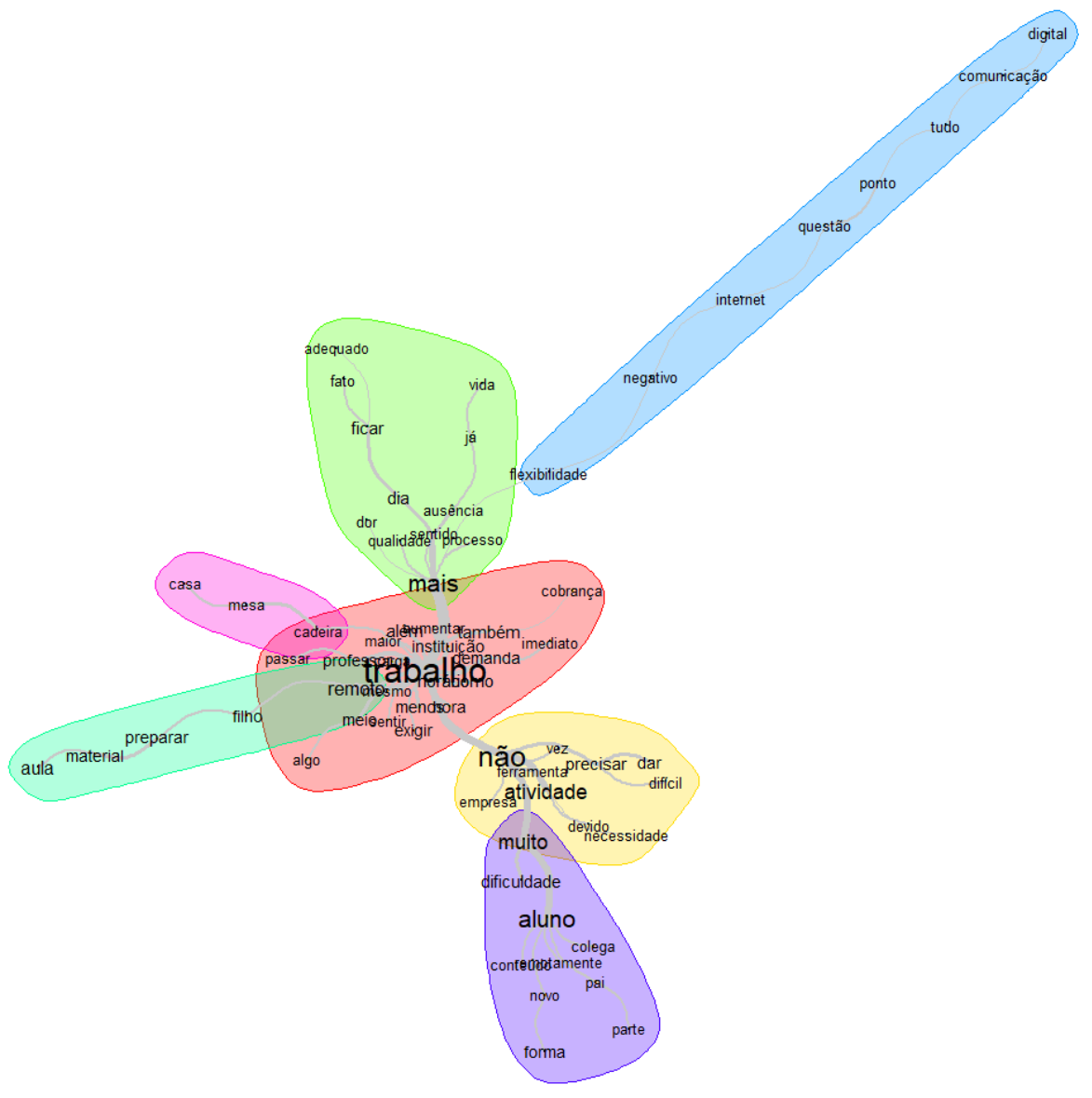

Fonte: Elaborado pelas autoras com base no Banco de dados setor educacional (2020) 
Por meio da análise de similitude por halo, identificou-se que as expressões mais organizadoras das representações dos/as professores/as foram "trabalho", "não”, "mais”, "aluno”, "como", "remoto". Na análise de similitude com halo, a interpretação dos segmentos textuais acusa que o grupo de respondentes da esfera privada apresenta como palavra central o "trabalho". Observa-se que nos halos que circundam o "trabalho", os segmentos textuais são: "não", "aluno", "mais", "como", "remoto".

Ao analisar individualmente cada halo, pode-se identificar os grupos de palavras que o acompanham, a saber, no halo vermelho em que a palavra "trabalho" ganha destaque, observa-se que o conjunto de palavras contemplado é "processo", "qualidade", "maior", "demanda", "remoto", "instituição”, "horário”, "imediato”, “cobrança”. O vínculo de tais palavras ao trabalho, evidencia a dinâmica que o processo de trabalho na modalidade remota assume, sendo impregnado pelo imediatismo das demandas que chegam aos docentes, mediado pelas TICs e pelo acesso irrestrito ao professor/a. A instantaneidade e atemporalidade dos processos de comunicação, no contexto do trabalho remoto, não é cercado por uma rotina de trabalho delimitada no tempo formal na jornada de trabalho, extrapolando as barreiras físicas quando adentra às residências desses trabalhadores; e não somente isso, também apaga as delimitações temporais entre tempo de trabalho e não trabalho.

No halo roxo, em que a palavra central é "aluno" aliam-se as palavras "novo", "colegas" e "forma". No halo rosa, observa-se a palavra "remoto", seguida de "filho", "flexibilidade" e "conteúdo". Interessante ressaltar que a flexibilidade é um ponto de positivação para o grupo pesquisado quando se refere ao trabalho remoto, sendo o principal aspecto apontado como positivo. A flexibilidade de horários e a adaptação dos processos de trabalho trazem consigo questões que o contexto peculiar pandêmico propôs, como o cuidado integral com os filhos, uma vez que as instituições escolares se encontravam fechadas. É importante demarcar o aspecto paradoxal aqui presente, pois o grupo pesquisado, para além de serem trabalhadores da educação, também são pais, mães, avós, tios, irmãos, ou seja, são sujeitos atravessados por outras demandas e complexidades, as quais interferem diretamente no processo de trabalho remoto.

Ainda, as dificuldades com relação à organização do trabalho podem ser observadas no seguinte relato: "Tenho dificuldade com a minha internet, mesmo tendo contratado uma velocidade maior depois da pandemia (120 megas) e o volume de trabalho aumentou consideravelmente". (Respondente 6, pesquisa de campo, 2020). Corrobora com essa percepção o respondente 52, cuja impressão sobre o ERE é vinculada com uma experiência de mais trabalho "não sei lidar com as TI, TI instáveis, não vejo colegas e alunos, mais demandas do que antes, não ter horário para trabalhar definido" (Respondente 52, pesquisa de campo, 2020).

Ainda com o foco na análise de similitudes, observa-se o halo azul, com a palavra "como" em destaque, podendo significar as percepções docentes sobre a organização do trabalho, e percebe-se a sequência de palavras "vida", "questão" e "negativo". Por fim, o halo verde conta com a palavra "não" como expressiva nas falas dos participantes, seguida de palavras como "necessidade", "dificuldade", "remotamente", "ferramenta" e "casa", e o halo amarelo, com a palavras "mais" em destaque seguida de "professor", "dia" e "ausência".

A partir das palavras em destaque nos halos da Figura 1, é possível visualizar que a experiência do trabalho remoto para os vinculados à esfera privada, no contexto da pandemia, é composta por percepções que indicam uma rotina de aumento do trabalho, dificuldades na organização do processo de trabalho, ausência de delimitações entre as atividades laborais e a vida particular. Seriam essas as mesmas percepções dos/as docentes vinculados ao setor público? 
Figura 2 - Análise de similitude das percepções docentes do trabalho remoto na esfera pública pelo software IRAMUTEQ

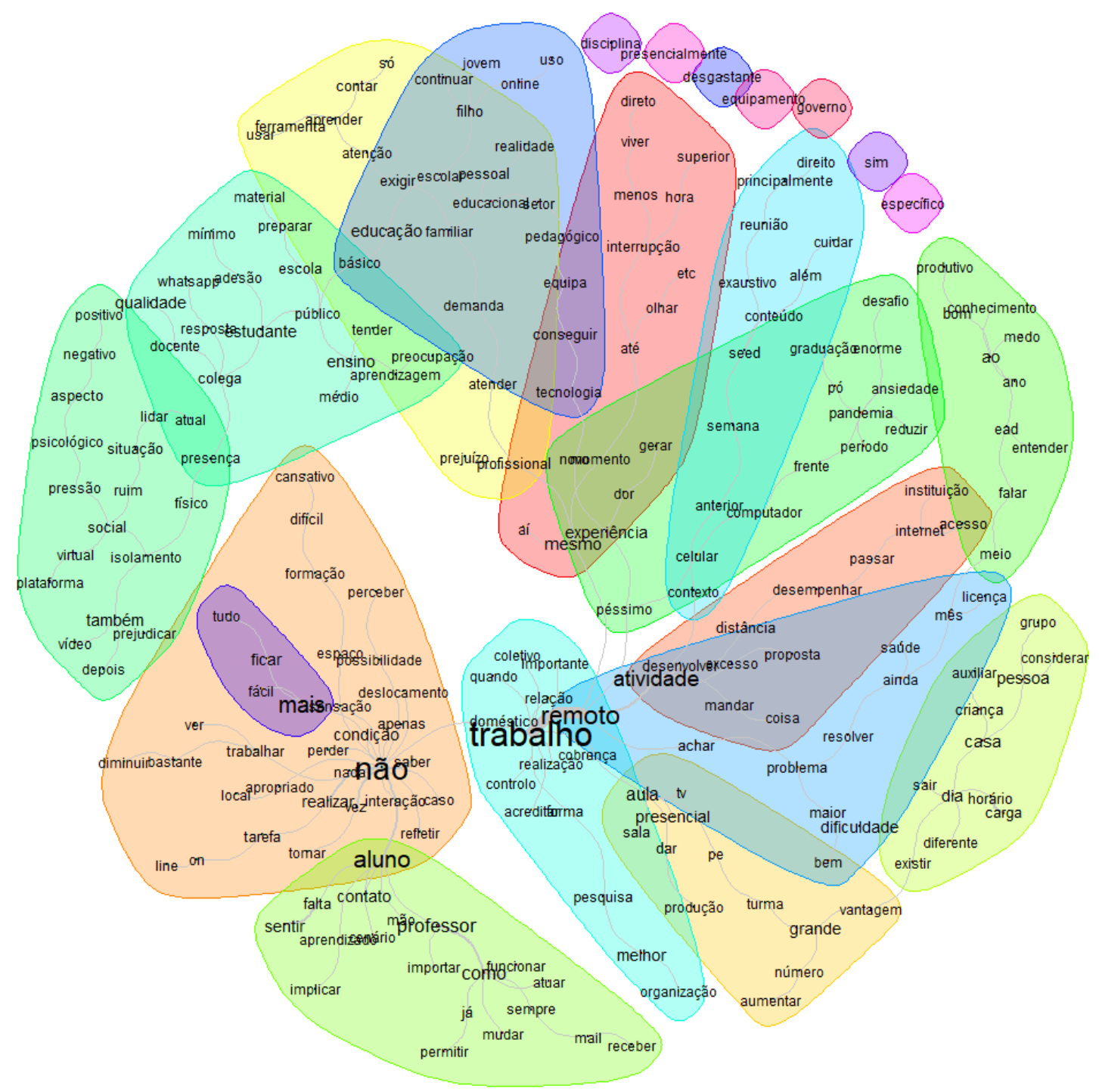

Fonte: Elaborado pelas autoras com base no Banco de dados setor educacional (2020)

A Figura 2 representa o registro das percepções a respeito do trabalho remoto por parte dos/as professores/as da esfera pública, a partir das respostas à questão 37, com o intuito de dar vistas aos principais problemas e vantagens a respeito dessa modalidade de trabalho. Por meio da análise de similitude por halo, identificou-se que as expressões mais organizadoras das representações participantes foram "trabalho", "remoto", "não", "aluno”, “atividades", "mais”.

A partir da figura acima, percebe-se que o grupo de respondentes da esfera pública apresenta como palavra central o "trabalho" com forte intersecção da palavra "remoto". Observa-se que nos halos que circundam o "trabalho", como o azul, por exemplo, os segmentos textuais são "controle”, "cobrança”, "doméstico", "aula”, "pesquisa”, “coletivo”, "produção”. Em função do maior número de respondentes pertencer a esfera pública, a figura apresenta-se mais complexa e com maior número de halos. Por este motivo, optou-se por interpretar aqueles cujas palavras são mais reincidentes. 
No halo rosa, a palavra "não" ganha destaque, seguida das palavras “interação”, “condição”, "perder”, "realizar", "tarefa”, "apropriado”, "local”, "on line”. A partir das falas dos professores da esfera pública, percebem-se dificuldades com o ensino remoto, sobretudo com as transposições das práticas presenciais para a modalidade remota. Também foi possível realizar a extração de fragmentos que expressaram tais dificuldades com relação à organização do trabalho, como é possível observar a partir do respondente n. 4: "Sinto-me invadida na minha privacidade. Meu local de lazer e descanso hoje é onde trabalho, essa confusão não nos permite descansar adequadamente. Muita cobrança de produção normal em situação adversa. Não encontro espaço para anseios, medos, surtos." (Respondente 4, pesquisa de campo, 2020).

Com relação ao halo verde oliva, no qual a palavra "aluno" ganha destaque, o conjunto de palavras que acompanham são "falta", "contato", "e-mail”, "sentir”, "permitir”, "implicar”. o respondente n. 27 aponta as dificuldades quanto às interações com os alunos na modalidade remota, a saber, "O trabalho é em dobro. Nós professores passamos a dedicar mais tempo para preparar material. $O$ atendimento aos alunos fica bem desgastante, pois não tem dia nem hora. Às vezes, sensação de solidão, de fingir que está ensinando". (Respondente 27, pesquisa de campo, 2020).

Por fim, o halo verde água, no qual a palavra "remoto" ganha relevância, tem uma característica interessante, pois faz intersecção com outros quatro halos nos quais as palavras reincidentes são "maior”, “dificuldade”, “problema”, “excesso”, “saúde”, “licença”, “criança”, "casa". Esse halo expressa alguns dos aspectos negativos do trabalho remoto e suas implicações na saúde e na vida pessoal dos/as docentes integrantes da pesquisa. A fala do respondente n. 239 é representativa: "Dificuldade de gerenciar as atividades domésticas e profissionais no mesmo ambiente. Além de ter que cuidar do filho ao mesmo tempo que está executando as atividades do trabalho". (Respondente 239, pesquisa de campo, 2020).

Ao correlacionar as percepções dos/as docentes de ambos os setores, público e privado, evidenciadas nas figuras 1 e 2, observa-se que há uma congruência no que tange às dificuldades quanto à organização do processo de trabalho na modalidade remota, acentuada pelo apagamento das barreiras que delimitavam o espaço e o tempo de trabalho e não trabalho. Reservadas as especificidades que as relações de trabalho assumem em cada setor, é possível inferir que as dificuldades quanto ao trabalho dos/as docentes na modalidade remota provocada pela pandemia, são similares nos dois setores.

Os achados da pesquisa encontram respaldo nas análises Antunes (2020), em que as contradições do trabalho remoto são indicadas. Os principais aspectos positivos do trabalho remoto são o ganho de tempo pela ausência de deslocamentos e a flexibilidade nos horários de trabalho. Porém, os pontos negativos estão no processo de trabalho como a individualização do trabalho, desconstrução das relações solidárias e coletivas, implicando no afastamento das experiências sindicais e fragilizando as possíveis resistências dos desmontes dos direitos vinculados ao trabalho (ANTUNES, 2020).

\section{Considerações finais}

O trabalho remoto para os/as docentes é multifacetado, assumindo dinâmicas plurais e ao mesmo tempo paradoxal, com realocamentos que avançam na intensificação do trabalho, no apagamento entre tempo de trabalho e vida privada, ao passo em que proporciona a essa categoria desenvolver seu trabalho de forma segura quanto à exposição ao vírus, à manutenção de seus trabalhos e de suas atividades, a economia com deslocamentos e maior convívio familiar. 
Analisar um fenômeno social ao mesmo tempo em que ele emerge, constitui-se em grande desafio, por se correr o risco de deixar escapar questões que, em princípio, podem parecer desconexas, mas que influenciam a dinâmica social. No entanto, o esforço de compreensão do trabalho remoto para os docentes no contexto da pandemia, sendo esse um fenômeno datado, complexo e cercado por determinações sociais e econômicas singulares, paradoxalmente, não está desconectado de movimentos mais amplos na esfera da gestão e organização do trabalho na sociedade capitalista atual.

As análises e referências sobre o trabalho remoto, realizadas antes da pandemia, são acionadas apenas como mediação do processo de compreensão do atual trabalho remoto. Uma vez que essa modalidade de trabalho, realizado no contexto da pandemia, não é a mesma, ela assume determinantes distintos, como a provisoriedade e a insegurança - em suas diversas facetas - e para sua análise é necessária a construção de novos referenciais teóricos. Assim, o presente estudo coloca-se no contínuo processo de pensar e repensar em que sentido seus resultados, provisórios, podem colaborar para compreender as realocações do trabalho remoto para os/as docentes, e ampliar a percepção sociológica desse fenômeno.

Embora o contexto da pandemia da COVID-19 tenha delineado um novo formato de trabalho para o setor educacional, essa (re)organização do trabalho docente ocorreu de maneira diversificada e até mesmo individualizada nos setores público e privado, conforme dados do campo dessa pesquisa. Enquanto as instituições privadas, a partir da continuidade ininterrupta das suas atividades, realizaram uma adaptação prematura da atuação docente da modalidade presencial para o ensino remoto emergencial, algumas instituições públicas buscavam formas de capacitar os professores para a modalidade remota e de auxiliar os estudantes no que tange ao acesso a equipamentos. Entretanto, não de maneira uníssona, as IES públicas também deram início, ao longo do primeiro semestre de 2020, aos usos das plataformas virtuais para, primeiramente, dar continuidade às atividades administrativas e de gestão, e na sequência, às atividades de ensino e pesquisa.

O exercício das atividades docentes na modalidade remota se apresentou como uma alternativa para que as aulas fossem retomadas e que os estudantes não tivessem prejuízos com relação ao cumprimento do ano letivo. E, nesse cenário, as condições objetivas de trabalho dos professores, tanto no setor público, quanto no setor privado, se caracterizam por rotinas exaustivas e intermináveis de um trabalho digital, com jornadas intensas. Longe de uma perspectiva de normalidade ainda em 2021, as atividades docentes permanecem sendo executadas na modalidade remota, os usos das tecnologias tornam-se cada vez mais conscientes pelos/as professores/as e instituições, mas não menos intensificados no processo de transposição das aulas virtuais para a modalidade remota. As regulações dessa modalidade de trabalho ainda são muito insipientes, permitindo que os processos de precarização sejam constantemente instrumentalizados, motivando um desmonte do ofício docente.

Nesse sentido, esse estudo nos desafia a pensar continuamente nas perspectivas futuras para as configurações do trabalho docente, sobretudo nas condições objetivas que se firmam no que aparenta ser um terreno fértil para a ampliação da flexibilização das relações de trabalho e da efetivação da precarização para essa categoria profissional. 


\section{Referências}

ANTUNES, Ricardo. Coronavírus: o trabalho sob fogo cruzado. São Paulo: Boitempo, 2020.

ANTUNES, Ricardo. O vilipêndio da COVID-19 e o imperativo de reinventar o mundo. O Social em Questão, v. 24, n. 49, jan./abr., 2021.

ANTUNES, Ricardo. Adeus ao trabalho?: ensaio sobre as metamorfoses e a centralidade do mundo do trabalho. 13. ed. São Paulo: Cortez, 2008.

BERNARDO, Kelen Aparecida da Silva. Flexibilização contratual no setor público: condições e relações de trabalho dos professores temporários nas universidades estaduais do Paraná. 2020. Tese (Doutorado em Sociologia) - Programa de Pós-Graduação em Sociologia, Universidade Federal do Paraná, Curitiba, 2020. Disponível em: encurtador.com.br/xABQZ Acesso em: 21 de jan. 2021.

BERNARDO, Kelen Aparecida da Silva; MAIA, Fernanda Landolfi; BRIDI, Maria Aparecida. As configurações do trabalho remoto da categoria docente no contexto da pandemia Covid-19. Revista Novos Rumos Sociológicos (NORUS), v. 8, n.14, p. 1-32, 2020. Disponível em: https://periodicos.ufpel. edu.br/ojs2/index.php/NORUS/issue/view/983/showToc Acesso em: 23 de abr. 2021.

BRASIL. Decreto-lei n. 5.452, de $1^{\circ}$ de maio de 1943. Aprova a Consolidação das Leis do Trabalho. Disponível em: http://www.planalto.gov.br/ccivil_03/decreto-lei/del5452.htm. Acesso em: 23 abr. 2021.

BRASIL. Instrução Normativa n. 65, de 30 de julho de 2020. Estabelece orientações, critérios e procedimentos gerais a serem observados pelos órgãos e entidades integrantes do Sistema de Pessoal Civil da Administração Federal - SIPEC relativos à implementação de Programa de Gestão. Disponível em: https://www.in.gov.br/en/web/dou/-/instrucao-normativa-n-65-de-30-de-julhode-2020-269669395. Acesso em: 6 maio 2021.

BRASIL. Lei n. 6.019, de 3 e janeiro de 1974. Dispõe sobre o Trabalho Temporário nas Empresas Urbanas, e dá outras Providências. Disponível em: http://www.planalto.gov.br/ccivil_03/leis/16019. htm. Acesso em: Acesso em: 12 jun. 2021

BRASIL. Medida Provisória n. 934, de $1^{\circ}$ de abril de 2020. Estabelece normas excepcionais sobre o ano letivo da educação básica e do ensino superior decorrentes das medidas para enfrentamento da situação de emergência de saúde pública de que trata a Lei no 13.979, de 6 de fevereiro de 2020. Disponível em: https://www.in.gov.br/en/web/dou/-/medida-provisoria-n-934-de-1-de-abrilde-2020-250710591. Acesso em: 6 maio 2021.

BRASIL. Ministério da Educação. Assessoria de Comunicação Social do MEC. Notícia. Comitê Operativo de Emergência monitora unidades de educação no combate à COVID-19. A finalidade é debater e definir medidas de combate à disseminação da pandemia da COVID-19 em instituições de ensino. 24 mar. 2021. Disponível em: encurtador.com.br/lvxIR. Acesso em: 19 jun. 2021.

BRASIL. Portaria n. 343, de 17 de março de 2020. Dispõe sobre a substituição das aulas presenciais por aulas em meios digitais enquanto durar a situação de pandemia do novo Coronavírus - COVID-19. Brasília: Casa Civil, 2020b. Disponível em: https://www.in.gov.br/en/web/dou/-/portaria-n-343-de-17de-marco-de-2020-248564376. Acesso em: 8 set. 2020.

BRASIL. Portaria n. 345, de 19 de março de 2020. Altera a Portaria MEC n. 343, de 17 de março de 2020c. Brasília: Casa Civil, 2020c. Disponível em: https://abmes.org.br/arquivos/legislacoes/Portariamec-345-2020-03-19.pdf. Acesso em: 8 set. 2020. 
BRASIL. Projeto de Lei n. 5.581, de 17 de dezembro de 2020. Dispõe sobre o teletrabalho, realizado fora das dependências do empregador, e altera disposições da Consolidação das Leis do Trabalho (CLT) e dá outras providências. Disponível em: encurtador.com.br/jvLV5. Acesso em: 12 jun. 2021.

BRIDI, Maria Aparecida. Teletrabalho em tempos de pandemia e condições objetivas que desafiam a classe trabalhadora. In: OLIVEIRA, Dalila Andrade; POCHMANN, Marcio. A devastação do trabalho: a classe do labor na crise da pandemia. Brasília: Positiva, 2020. p. 173-205.

CASTRO, Bárbara Geraldo de. Afogados em contratos: o impacto da flexibilização do trabalho nas trajetórias dos profissionais de TI. 2013. Tese (Doutorado em Sociologia) - Universidade de Campinas, Campinas (SP), 2013.

DAL ROSSO, Sadi. Mais trabalho: a intensificação do labor na sociedade contemporânea. São Paulo: Boitempo, 2008.

GUSSO, Hélder Lima; et al. Ensino superior em tempos de pandemia: diretrizes à gestão universitária. Educação \& Sociedade, v. 41, e238957, 2020. Disponível em: https://www.scielo.br/j/es/a/pBY83877Z kLxLM84gtk4r3f/?format=pdf\&lang=pt. Acesso em: 12 jun. 2021.

HODGES, C.; et al. The difference between emergency remote teaching and online learning. Educause Review, 2020. Disponível em: https://er.educause.edu/articles/2020/3/the-differencebetweenemergency-remote-teaching-and-online-learning\#fn3. Acesso em: 16 maio 2020.

MAIA, Fernanda Landolfi. o paradoxo da intensificação: uma análise do trabalho dos professores de ensino superior público federal. Tese (Doutorado em Sociologia) - Universidade Federal do Paraná, Curitiba, 2014. Disponível em: https://acervodigital.ufpr.br/handle/1884/37352. Acesso em: 11 out. 2020.

MAIA, Fernanda Landolfi; BERNARDO, Kelen Aparecida da Silva. O trabalho docente e o setor educacional. In: BRIDI, Maria Aparecida da Cruz (coord.). Relatório técnico da pesquisa: trabalho remoto/home-office no contexto da pandemia COVID-19: parte II. Curitiba: GETS/UFPR; REMIR, 2020a. Disponível em: https://www.eco.unicamp.br/remir/index.php/remir-2 . Acesso em: 18 out. 2020.

MANCEBO, Denise. Trabalho remoto na educação superior brasileira: efeitos e possibilidades no contexto da pandemia. Revista USP, n. 127, p. 105-116, 2020. Disponível em: https://www.revistas.usp. br/revusp/article/view/180086/166676. Acesso em: 18 abr. 2021.

MINAYO, Maria Cecília de Souza. o desafio do conhecimento: pesquisa qualitativa em saúde. 14. ed. São Paulo: Hucitec, 2014.

MPT (Ministério Público do Trabalho). Procuradoria Geral do Trabalho. Nota técnica: GT COVID 19. nov. 2020. Disponível em: https://abmes.org.br/arquivos/documentos/nota-tecnica25062020.pdf. Acesso em: 31 maio 2021.

OIT (Organização Internacional do Trabalho). A COVID-19 e o setor da educação. Síntese setorial OIT. 16 abr. 2020. Disponível em: https://www.ilo.org/wcmsp5/groups/public/---europe/---ro-geneva/--ilo-lisbon/documents/publication/wcms_746836.pdf. Acesso em: 21 maio 2021.

OLIVEIRA, Daniela Ribeiro de. Do fim do trabalho ao trabalho sem fim: o trabalho e a vida dos trabalhadores digitais em home office. 2017. Tese (Doutorado em Sociologia) - Universidade Federal de São Carlos, São Carlos (SP), 2017. Disponível em: https://repositorio.ufscar.br/handle/ufscar/10792. Acesso em: 14 mar. 2021.

PEREIRA, Eva Waisros; MORAES Raquel de Almeida. História da educação a distância e os desafios na formação de professores no Brasil. In: SOUZA Amaralina Miranda de; FIORENTINI, Leda Maria 
Rangearo; RODRIGUES, Maria Alexandra Militão (Orgs.). Educação superior a distância: comunidade de trabalho e aprendizagem em rede (CTAR). Brasília: UnB, 2020.

SANTOS, Boaventura de Sousa. A universidade pós-pandêmica. Outras Palavras, 2 jul. 2020. Disponível em: https://outraspalavras.net/alemdamercadoria/boaventura-a-universidade-pos-pandemica. Acesso em 27 abr. 2021.

VASCONCELOS, Silmar. Sistematização e organização da base de dados de pesquisa científica de vitivinicultura para a criação do conhecimento na EPAMIG. 2018. Projeto de Dissertação (Mestrado Profissional em Sistemas de Informação e Gestão do Conhecimento) - Universidade FUMEC, Faculdade de Ciências Empresariais, Belo Horizonte, 2018. 